\title{
Transition from US GAAP to IFRS: Analysis of Impact on Income Tax Administration in USA $^{\#}$
}

\author{
Jana Roe
}

\section{Introduction}

Tax reporting versus financial statement reporting have different objectives, and, depending on the jurisdiction, can result in more or less similar sets of reporting rules and a unique mix of legal, regulatory and financing aspects of the environment. Regarding the relationship between tax and accounting, worldwide tax collections constitute the greatest source of demand for accounting services (IBISWorld, 2014). From cash flow point of view, taxes on income, both on the individual and business enterprise level, constitute the largest source of revenue for governments of countries with literate populations (Seidler, 1991). Based on prior research, it may appear that the tax theory behind the collection of tax revenue outweighs the importance of accounting theory; however, in most jurisdictions, accounting results are usually the starting point or bases for calculating taxable results, such as is the case in the United States of America (USA). Therefore, the importance of understanding and ability to work with accounting results and related theory for tax collection and administration is extremely important.

One of the most relevant factors in categorizing tax systems is the degree to which tax regulations determine accounting measurements and vice versa, which is to a certain extent evidenced by deferred taxation, which is caused by differences between tax and accounting system in a given jurisdiction. In the US, for example, the problem of deferred tax has caused controversy and a considerable amount of accounting standard

\# This article has been prepared under the research project Assumptions for Introduction of the IFRS as an Alternative Tax Base in a Small Open Economy: Evaluation of Its Impact on Country's Competitiveness supported by the Czech Science Foundation under the registration number P403/12/1901.

Jana Roe, Ph.D., CPA - Lecturer; Faculty of Finance and Accounting, University of Economics, Prague, W. Churchill Sq. 4, 13067 Prague, Czech Republic; <xroej900@vse.cz>. 
documentation. Contrasted by the relationship of tax and accounting rules for example in the Czech Republic, the deferred taxation problem is relatively minor, due to the close resemblance of tax and accounting rules and how state regulations compensate for the shift to IFRS.

With respect to financial reporting, research shows that recent developments can be characterized as a deliberate and gradual shift away from balance sheet reporting of historical costs, to the reporting of current (fair) values (Ratcliffe, 2007). Financial accounting, represented by the United States Generally Accepted Accounting Principles (US GAAP), as well as tax reporting within USA, as opposed to International Financial Reporting Standards (IFRS), has retained a greater adherence to the historical cost principle, something that is causing greater need for analysis of tax calculations, which involve IFRS as a starting point. However, with convergence efforts between US GAAP and IFRS, the trend of moving toward current values is also showing in US GAAP. From tax perspective, in USA, the Internal Revenue Service (IRS), is preparing for a full switch to IFRS, which includes various activities, involving both the technical (rule-related) and the non-technical (procedure and regulation related) aspects of conversion from US GAAP to IFRS. Recognizing that US companies compete for capital in a global marketplace, the US Securities and Exchange Commission (SEC) is moving to allow large companies to begin using IFRS. This transition will not only impact financial statement preparers, it will also have a noticeable effect on tax professionals, due to the intertwined relationship of the tax rules and regulations embedded in US GAAP (Mulyadi, Soepriyanto, \& Anwar, 2012).

With respect to financial reporting, research shows that recent developments can be characterized as a deliberate and gradual shift away from balance sheet reporting of historical costs, to the reporting of current (fair) values (Ratcliffe, 2007). Financial accounting, represented by the United States Generally Accepted Accounting Principles (US GAAP), as well as tax reporting within USA, as opposed to International Financial Reporting Standards (IFRS), has retained a greater adherence to the historical cost principle, something that is causing greater need for analysis of tax calculations, which involve IFRS as a starting point. However, with convergence efforts between US GAAP and IFRS, the trend of moving toward current values is also showing in US GAAP. From tax perspective, in USA, the Internal Revenue Service (IRS), is preparing for a full switch to IFRS, which includes various activities, involving both the technical (rule-related) and the non-technical 
(procedure and regulation related) aspects of conversion from US GAAP to IFRS. Recognizing that US companies compete for capital in a global marketplace, the US Securities and Exchange Commission (SEC) is moving to allow large companies to begin using IFRS. This transition will not only impact financial statement preparers, it will also have a noticeable effect on tax professionals, due to the intertwined relationship of the tax rules and regulations embedded in US GAAP (Mulyadi, Soepriyanto, \& Anwar, 2012).

This research article identifies and describes the major tax-related considerations and elements relevant to a transition from US GAAP to IFRS, including analysis of the technical, regulatory and organizational aspects as perceived by the IRS. The first section explores the link between taxation and accounting and summarizes recent research in this area; the next section covers the state of preparedness of IRS for the adoption of IFRS for financial reporting. State tax considerations as well as non-technical issues related to the transition to IFRS are presented in separate sections. Direction for further research is offered in the conclusions of this paper.

\section{Link between taxation and accounting}

Based on recent research (eg. Leuz, Pfaff \& Hopwood, 2010 or Jaggi $\&$ Low, 2000), taxation may have a strong influence on the accounting practice within a jurisdiction, especially for accounting measurements. Countries have different national tax systems, which define most directly and most frequently the conduct of business and also the practice of accounting. In many countries, law, and particularly tax law, is the only reason that accounting is done at all. In these countries accounting rules and practices are spelled out in laws, often called companies' acts, which also contain the general laws for all business operations and activities. In most of these countries, there is no difference between tax accounting and financial accounting. For example in Germany, the tax accounts were required to be the same as the commercial accounts before 1983 (Seidler, 1991). Tax laws in virtually all jurisdictions specify accounting procedures to be used in the tax area and in some countries, such as USA, published accounts are designed particularly as performance indicators for investment decisions, where commercial rules generally operate separately from tax rules.

The current relationship of accounting and taxation in USA is such that financial reporting is regulated by the SEC via US GAAP, which is 
formed by an independent professional organization, the Financial Accounting Standards Board (FASB), versus the tax administration is regulated by federal and state laws, specifically on the federal level, it is via the Internal Revenue Code (IRC), a subset of the US Code of Law. The difference between financial and tax accounting rules partially creates the tax gap, exemplified by the deferred taxation issue related to the timing of deductions or recognition of revenues; research in this area has historically focused on case studies which chart jurisdiction's move from close connection to separation over a period of time (Nobes \& Schwencke, 2006). To illustrate the diverse relationship between financial reporting and taxes, based on a PwC survey published in 2013, Figure 1 is presented below.

Fig. 1: Comparison of financial reporting and tax regimes

\begin{tabular}{|c|c|c|c|c|}
\hline $\begin{array}{l}\text { Name of } \\
\text { Country }\end{array}$ & $\begin{array}{c}\text { Use of IFRS } \\
\text { for publicly } \\
\text { traded } \\
\text { companies }\end{array}$ & $\begin{array}{l}\text { Type of tax } \\
\text { regime }\end{array}$ & $\begin{array}{c}\text { IFRS } \\
\text { permitted as } \\
\text { a starting } \\
\text { basis for tax } \\
\text { reporting }\end{array}$ & $\begin{array}{c}\text { Tax acts } \\
\text { changed } \\
\text { as a } \\
\text { result of } \\
\text { IFRS } \\
\text { adoption }\end{array}$ \\
\hline China & $\begin{array}{l}\text { No, however } \\
\text { local } \\
\text { standards are } \\
\text { substantially } \\
\text { similar to } \\
\text { IFRS }\end{array}$ & $\begin{array}{c}\text { Quasi- } \\
\text { dependent }\end{array}$ & $\begin{array}{l}\text { NO - however } \\
\text { local standards } \\
\text { are } \\
\text { substantially } \\
\text { similar to } \\
\text { IFRS }\end{array}$ & NONE \\
\hline $\begin{array}{c}\text { Czech } \\
\text { Republic }\end{array}$ & $\begin{array}{l}\text { Adopted } \\
\text { IFRS in } \\
2005\end{array}$ & $\begin{array}{c}\text { Quasi- } \\
\text { dependent }\end{array}$ & NO & \\
\hline France & $\begin{array}{l}\text { Adopted } \\
\text { IFRS in } \\
2005\end{array}$ & $\begin{array}{c}\text { Quasi- } \\
\text { dependent }\end{array}$ & NO & NONE \\
\hline Germany & $\begin{array}{l}\text { Adopted } \\
\text { IFRS in } \\
2005\end{array}$ & Independent & NO & NONE \\
\hline Switzerland & $\begin{array}{l}\text { Adopted } \\
\text { IFRS in } \\
2005\end{array}$ & Dependent & NO & NONE \\
\hline
\end{tabular}




\begin{tabular}{|c|c|c|c|c|}
\hline $\begin{array}{c}\text { Name of } \\
\text { Country }\end{array}$ & $\begin{array}{c}\text { Use of IFRS } \\
\text { for publicly } \\
\text { traded } \\
\text { companies }\end{array}$ & $\begin{array}{c}\text { Type of tax } \\
\text { regime }\end{array}$ & $\begin{array}{c}\text { IFRS } \\
\text { permitted as } \\
\text { a starting } \\
\text { basis for tax } \\
\text { reporting }\end{array}$ & $\begin{array}{c}\text { Tax acts } \\
\text { changed } \\
\text { as a } \\
\text { result of } \\
\text { IFRS } \\
\text { adoption }\end{array}$ \\
\hline $\begin{array}{c}\text { United } \\
\text { Kingdom }\end{array}$ & $\begin{array}{c}\text { Adopted } \\
\text { IFRS in } \\
2005\end{array}$ & $\begin{array}{c}\text { Quasi- } \\
\text { dependent }\end{array}$ & YES & YES \\
\hline USA & $\begin{array}{c}\text { IFRS } \\
\text { permitted for } \\
\text { foreign } \\
\text { companies } \\
\text { but not for } \\
\text { domestic } \\
\text { companies }\end{array}$ & Independent & $\begin{array}{c}\text { YES - } \\
\text { Reconciliation } \\
\text { between } \\
\text { financial result } \\
\text { (can be } \\
\text { determined } \\
\text { using US } \\
\text { GAAP or }\end{array}$ & NONE \\
& & $\begin{array}{c}\text { IFRS) and tax } \\
\text { result required }\end{array}$ & \\
\hline
\end{tabular}

Source: Compiled by the author based on information from PwC published in 2013.

Explanation of type of tax regime:

- Dependent (tax result based entirely on result according to local statutory accounting rules)

- Quasi-dependent (tax result based on book result with some adjustments prescribed in tax law)

- Independent (accounting rules and tax law are independent of each other)

The issue of book and tax conformity in USA has been researched heavily and over time crystalized in a debate between proponents of book and tax conformity such as Chan et al (2010), where the authors investigate whether a departure from a tax-based accounting system toward the adoption of IFRS encourages tax noncompliance and whether such a departure, which weakens book-tax conformity, affects the informativeness of book-tax differences for tax noncompliance. Chan found that book-tax conformity decreases, tax noncompliance increases. Although book-tax differences remain informative of tax noncompliance, the informativeness attenuates as book-tax conformity weakens. 
Additionally, firms with high incentives to inflate book income are more tax compliant than their counterparts after the departure from a tax-based accounting system. Opponents of book and tax conformity such as Hanlon et al. (2008) find that increasing book-tax conformity has an unintended capital market consequence; namely, it results in accounting earnings that are less informative than they would be otherwise. Most recently, Baylock et al. (2013) analyzed the association between book and tax conformity and earnings management, finding that higher book-tax conformity is associated with significantly more, not less earnings management.

Tension is gradually increasing between the mark-to-market (fair value) accounting supported by IFRS and with convergence efforts, increasingly also by US GAAP, the SEC and the accounting profession in USA, and the historical value approach supported by the IRS, US courts and legislators, who have recently waged an attack on the mark-to-market method for tax accounting (Spalding, 2011). This tension has created a widening tax gap between financial and tax accounting in USA and Spalding concludes that the widening gap has two main effects; macroeconomic and microeconomic. The macroeconomic effect would be represented by a difference between tax and financial results, because IRS's objective is a clear reflection of income, versus FASB's objective is a fair representation of economic activities, theoretically, these goals do not seem very different but the results are often very different. The microeconomic impact would be an extra burden on taxpayers, who must maintain two sets of books, supported by separate accounting information systems and reporting; however, Spalding does not attempt to quantify either effect (Bothwell, 2009).

\section{Tax administration in the USA prepares for IFRS}

As with other jurisdictions, the dynamic relationship of tax and financial accounting and reporting in USA is a subject of a debate in literature among academics, professionals, standard setters and others, while business organizations and other reporting entities are caught in the middle. They are required to comply with both accounting and reporting regimes, and so they must continually develop and maintain information systems that properly support both US GAAP and tax calculations. Historically, US domestic companies that prepare their financial statements according to US GAAP compute their income tax using their accounting result modified by tax adjustments and report their 
computations on Form 1120, U.S. Corporation Income Tax Return and Schedule M-3, Net Income (Loss) Reconciliation for Corporations With Total Assets of \$10 Million or More.

In 2007, the SEC allowed foreign corporations that prepare their financial statements using IFRS as formulated by the IASB to use those financials for SEC filing without reconciliation to US GAAP, as previously required, and currently, it is estimated that over 450 foreign companies file their financial information with the SEC without reconciliation from IFRS to US GAAP, with capitalization in the trillions of US dollars (PWC, 2014). US domestic filers are still required to use US GAAP and are not permitted to use IFRS. Similarly, in the past, the tax regulations allowed for only US GAAP to be used as a starting point for tax calculations; however, since 2009, the IRS also permits taxpayers to use IFRS for the computation of worldwide-consolidated net income, which is a starting point for the taxable income calculations. US GAAP and IFRS are not the only permitted accounting standards used for the calculation of worldwide consolidated net income or loss, other permitted accounting standards are statutory, tax-basis or other. Simple visualization of the accounting standards and taxable income relationship is presented in Fig. 2: Relationship of IFRS, US GAAP and taxable income.

Since both IFRS and US GAAP are currently allowed as a starting point for tax computation in USA, it is important from the technical standpoint what accounting rules are currently in effect and which ones will be changing so the U.S. Internal Revenue Service (IRS) can focus on the most important issues that will be impacting tax revenues. From an environmental perspective, since major US companies still use US GAAP, and the IRS has deep knowledge and familiarity of use, regulators must keep up with changing international sentiment to financial reporting and prepare the tax environment for a smooth transition to IFRS. 
Fig. 2: Relationship of IFRS, US GAAP and taxable income

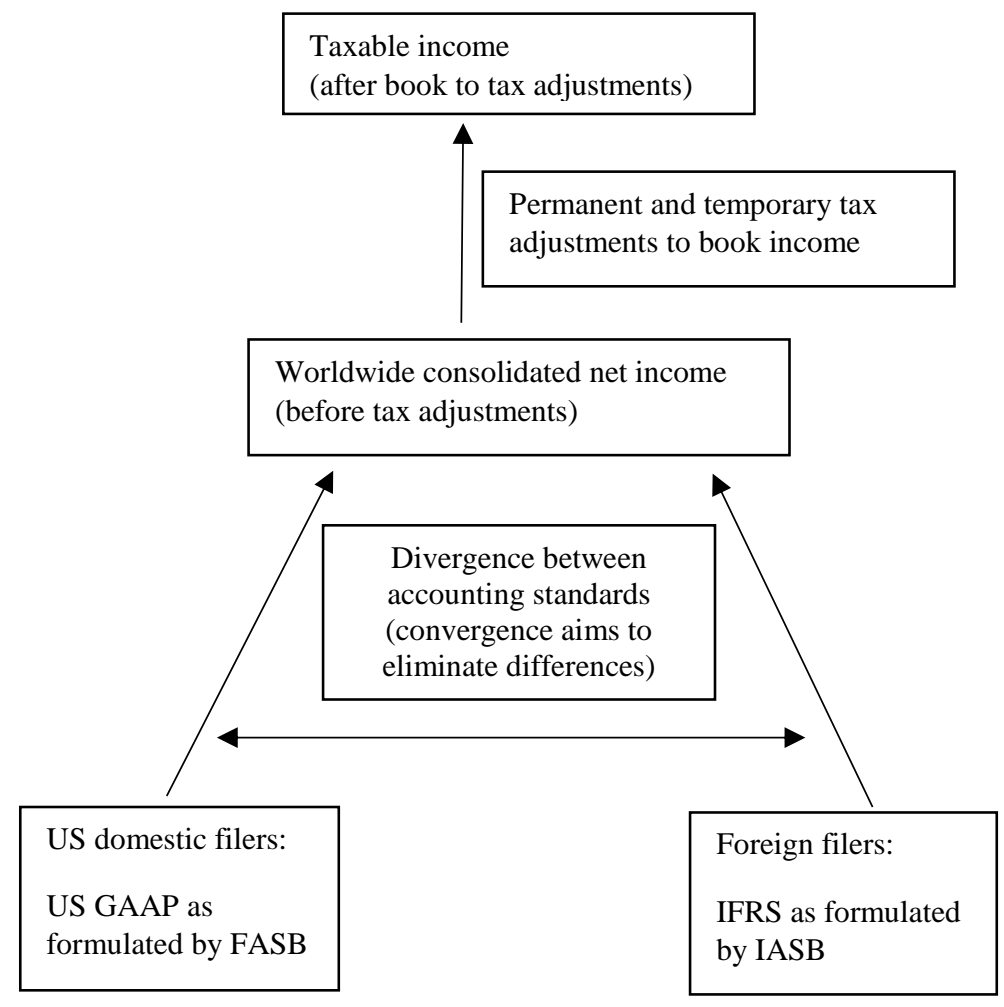

Source: Author's work based on currently enacted US tax laws.

Although the goals and rules under the two accounting systems are different, in practice, tax calculations heavily rely on book numbers, which makes it extremely important for the tax administration in USA to understand the move to IFRS thoroughly. Already in 2009, more than 220 companies used IFRS as a starting point in computing their federal taxable result; concurrently, IRS produced a strategic plan in the case of IFRS adoption in USA and subsequently, in 2010, Treasury Inspector General for Tax Administration (TIGTA) issued a report on the actions that are being taken to address the impact that IFRS will have on the tax administration (IRS, 2010).

Furthermore, differences between net income and the tax base are divided into temporary and permanent, where only temporary differences give rise to deferred tax assets and liabilities, which means, that if the tax rules remain constant, unchanged, using a divergent starting points for tax base calculation will result also in divergence in tax results. Since the US 
tax administration understands that any potential impact to the tax base would also impact the amount of taxes collected from taxpayers, the IRS is already preparing for the impact of potential transition of US publicly held companies to IFRS.

The likelihood of an ultimate transition from US GAAP to IFRS remains high, however, the steps identified by the SEC necessary to be completed before a decision on IFRS is made, were not completed by the original deadline of 2011, as well as convergence efforts on several standards have stopped, therefore the transition year to IFRS cannot be predicted with absolute certainty (FASB, 2013). Regardless, from tax administration point of view, the transition to IFRS will involve not only technical but also non-technical issues. In their 2010 report, TIGTA recognizes that IFRS will have an impact on both the administration and the taxpayer (IRS, 2010) and described IRS activities in preparation for IFRS adoption, which included:

- providing awareness training to IRS employees and managers by introducing them to IFRS concepts and potential issues;

- providing technical advice and guidance to employees conducting examinations of returns filed based on the IFRS;

- working with the tax preparer community to identify and outline IFRS implementation concerns;

- developing procedures to address issues related to IFRS conversion efforts;

- identification of a multi-functional working group, referred to as the IFRS Team that plans and monitors ongoing IFRS activities.

The IRS Large and Mid-Size Business Division's strategic initiatives in 2009 included developing a strategy to address the consequences of the expected conversion to the IFRS. The IRS is currently positioning itself to address the impact that the IFRS will have on tax administration and the taxpayer, which includes engaging with tax professionals who provide tax advice on international administrative, technical, and information reporting matters, to identify and monitor emerging issues related to the adoption of the IFRS. The IRS also conducted a review, where the overall objective was to assess the IRS' progress to prepare for the tax issues and implications of converting to IFRS (IRS, 2010). The IFRS Team created a general presentation for tax practitioners that provides information on: 
- IFRS background;

- IFRS usage by other countries;

- the potential SEC decision to convert to the IFRS in the US;

- joint FASB and IASB convergence efforts to resolve key differences;

- major remaining differences between US GAAP and IFRS;

- audit techniques on tax returns using IFRS as a starting point for tax calculation;

- resources for obtaining additional IFRS information.

The IFRS Team is currently overseeing an Issue Focus Group (IFG) that is addressing issues related to IFRS conversion efforts and consists of the IFRS Team's technical advisors and subject matter experts within the IRS who have been selected to review, in relation to specific issues and topics, the differences between US GAAP and the IFRS. The IFG will be responsible for creating guidance, by topic, which will serve as audit aids for IRS employees who conduct examinations of tax returns and he TIGTA plans to review the guidance and procedures once the IRS has fully implemented them. Furthermore, the IFRS Team designed a standardized template to assist the IFG in creating the audit aids and to ensure consistency in format. The required sections include an overview of the issue or topic, a description of the related standards under US GAAP and the IFRS, differences between the standards; the related US tax implications, and suggested audit techniques. The overall objective of this review was to assess the IRS' progress to prepare for the tax issues and implications of converting from US GAAP to the IFRS. To accomplish this objective, the IRS:

- Identified the actions taken or planned to be taken by the IRS to prepare and train employees to handle changes resulting from conversion to the IFRS.

- Identified the actions taken or planned to be taken by the IRS to establish and/or revise procedures to correspond with changes resulting from conversion to the IFRS.

- Identified the actions taken or planned to be taken by the IRS to provide information and support to the taxpayer community 
(taxpayers and representatives) to handle changes resulting from conversion to the IFRS.

- Identified the actions taken or planned to be taken by the IRS to create and/or revise tax forms and instructions to correspond with changes resulting from conversion to the IFRS.

- Identified the actions taken by the IRS to address the impact of the SEC's removal of the requirement for non-U.S. companies reporting financial results using the IFRS to reconcile to U.S. GAAP.

Based on their recent activities, it is clear that the US tax administration is preparing for IFRS very thoroughly and can be used as a benchmark for other countries who either plan to or have already adopted IFRS. The quality of tax administration and enforcement has been found to influence the quality of financial accounting (Nobes \& Parker, 2012) and in particular, countries with strong regulatory and enforcement frameworks, such as USA, are better equipped to administer both tax and financial accounting rules and presumably prepare themselves better for major changes.

\section{Specific technical tax issues impacted by adoption of IFRS in USA}

The following are the main technical tax issues related to the transition from US GAAP to IFRS that have been identified and described in prior literature and academic research:

- LIFO

- Leases

- Component depreciation

- Revenue recognition

- Capitalization of research and development

- Mark-to-market accounting

- Transfer pricing

- State tax apportionment

- Uncertain tax positions 
To illustrate the potential impact of these changes to accounting net income that would impact taxable income are explained in detail below. However, the issues listed above are not all exhausting, many smaller issues have not been discussed and researched by academics because they presumably do not have a material impact on the tax result. So far, only one paper attempted to quantify the impact of IFRS adoption in the USA, in the LIFO area (Mulford \& Comiskey, 2008), other papers discuss the technical issues but do not quantify the impact. A detailed study quantifying the impact of IFRS adoption on federal and state income taxes has not been published, one of the reasons is that tax data is not as available as financial reporting data. Another reason is that each company's tax situation is unique and in the USA, where taxpayers have to consolidate their filing for federal income taxes, combine and apportion their filings for state income taxes, and comply with other informational and non-income tax requirements, which often rely and use in calculations financial results, the impact of the switch to IFRS will be hard to estimate on collective basis without considering and analysing the possibility of unique situations of enterprises and their tax planning strategies.

More importantly, the tax accounting method implications of an IFRS conversion could have a direct impact on a company's cash taxes. For example, it is expected that cash taxes could be negatively affected as a result of the inability to use the LIFO inventory method, the potential change in business practices related to leasing, and the acceleration of book recognition of advance payments. Following is a discussion of individual accounting rule changes potentially applicable when IFRS replaces US GAAP and their impact on the tax calculation.

\subsection{LIFO}

The definition of inventory pursuant to International Accounting Standard (IAS) 2, Inventories, is similar to the US GAAP definition under Accounting Standards Codification (ASC) 330, Inventory; however, the last in, first out (LIFO) method of accounting is prohibited under IAS 2 (where other cost flow assumptions such as first in, first out (FIFO) and the weighted average cost methods are permitted). Currently, the LIFO conformity rules in IRC Section 472(c) provide that a taxpayer electing LIFO for income tax purposes must also elect LIFO for financial reporting purposes. Hypothetically, if taxpayers are forced to change their accounting method from LIFO to FIFO, they could be required to collapse their LIFO layers and, thus, take into income the recapture of the 
LIFO reserves. A question then arises as to whether the IRS will provide some type of relief from the above scenario resulting from the elimination of LIFO for book purposes.

As a result, a company that converts to IFRS will have to terminate any LIFO elections for tax unless a legislative or administrative exception is provided to the book conformity requirement. Termination of LIFO generally will result in the recapture of the tax LIFO reserve over four taxable years, though longer spread periods have been proposed. The trend in USA has been focused on liquidating LIFO layers, resulting in decreasing LIFO usage and is expected to be eliminated entirely overtime, as illustrated in Fig. 3: Decrease of major LIFO reserves in USA from 2007 to 2013, where major US companies with the largest LIFO reserves in 2007 were compared to their current LIFO levels in 2013 and a clear trend emerged toward reducing LIFO inventories.

\section{Fig. 3: Decrease of major LIFO reserves in USA from 2007 to 2013}

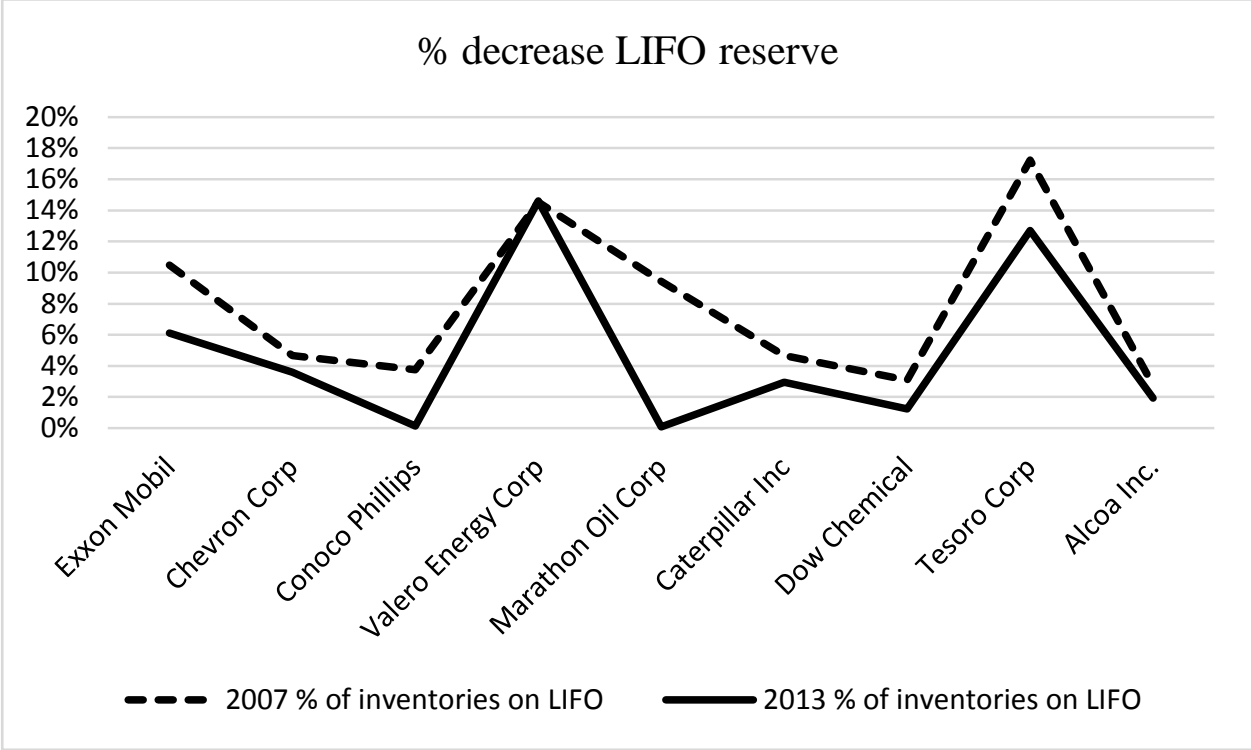

Source: Created by the author based on Forms 10-K for years 2007 and 2010, data obtained from SEC.

An example of best practices related to IFRS readiness efforts within tax departments is illustrated by the following IRS field advice from 2011, when the IRS posted a Memorandum of Legal Advice concluding that a taxpayer's providing financial statements prepared using IFRS to its lending bank violated the LIFO conformity requirements (IRS.gov, 2011). 
In this case, the taxpayer's foreign parent required the taxpayer to adopt IFRS to facilitate the processing of preparing worldwide-consolidated financial statements. The taxpayer had used, and continued to use, the LIFO inventory method for a portion of its inventory for both tax and financial reporting purposes. The taxpayer provided the IFRS-only balance sheet and income statement to its lending bank, related to lending requirements imposed by the bank related to a letter of credit. It also provided tabulated financial statements (including LIFO adjustments) to the IFRS column to arrive at US GAAP. However, the taxpayer did not make a distinction between primary or supplemental information with these financial statements and did not include explanatory footnotes regarding the change. The IRS concluded that the documents did not meet the exception for supplemental or explanatory information, and that the issuance of these financial statements to the lending bank violated the LIFO conformity requirements.

\subsection{Leasing}

Under ASC 840-30, Capital Leases, the character of a transaction as either a sale or a lease generally is determined based on form-driven, bright-line, mechanical rules; by contrast, the tax law requires under IRC Section 4217 a substance-over-form analysis of which party has the benefits and burdens of ownership of the property. These differences between US GAAP and tax law could allow companies to achieve favourable results for both book and tax, whereby the transaction is treated as a sale or financing transaction for books under which gain is recognized and as a lease for tax under which no gain is recognized and depreciation is claimed. For example, the requirement that a transaction be treated as a sale under US GAAP if the minimum lease payments equate to $90 \%$ or more of the value of the leased property could create a difference between accounting and tax results, if in substance, the tax law characterizes this transaction as a true lease based on all the facts and circumstances including whether the leased property has residual value.

Similar to the tax law, under IAS 17, Leases, IFRS also requires a substance-over-form analysis of which party has the risks and rewards of ownership; however, under IFRS certain factors individually may determine the characterization of a purported lease whereas under the tax law no single factor is dispositive. For example, under IFRS, a transaction must be treated as a sale if the minimum lease payments amount to substantially all of the value of the leased property. In practice, "substantially all" could be interpreted as $90 \%$ or more of the value of 
the leased property making the IFRS determination identical to GAAP. Nonetheless, because both the tax law and IFRS theoretically require a substance over form analysis, the possibility that the book to tax difference related to the characterization of leasing transactions could be eliminated upon conversion to IFRS should be considered. To the extent the IFRS and tax characterization are the same, if a company desires to recognize gain for books, it could be required to structure the transaction as a sale or financing transaction and recognize gain for tax purposes as well.

Furthermore, a new accounting standard for leasing activities is currently being considered by both FASB and IASB, which would unify the treatment for both US GAAP and IFRS, with the right of use model of accounting for leases, where all assets and liabilities of a lease arrangement are capitalized regardless of potential classification. According to IASB's website, leasing is a global business, and differences in accounting standards can lead to considerable noncomparability and that is why he joint IASB and FASB project seeks to improve the accounting for leases by developing an approach that is more consistent with the conceptual framework definitions of assets and liabilities. The project would result in a replacement of IAS 17, Leases. An earlier G4+1 Study had recommended capitalizing property rights inherent in all leases. Current status of the project ED/2013/6 Leases was published in May of 2013 and the finalized IFRS is expected during the second half of 2015. The economic impact has been quantified by several papers, namely by Seay and Woods in 2012.

\subsection{Component depreciation}

GAAP allows, but IFRS requires, use of component depreciation, under which an asset is broken down into its significant components for purposes of determining depreciation, disposals, and repairs. Thus, under IFRS, an airplane likely would be treated as several different assets, including the airframe, each engine, and wheels and brakes. The tax law, on the other hand, defines the relevant unit of property more broadly; generally examining whether a component is functionally interdependent with another component. In fact, the court in FedEx Corporation v. United States (291 F.Supp.2d 699) determined that an airplane and all its functionally interrelated parts, including the engine, constitute a single unit of property for tax purposes. 
As a result, it is likely that the unit of property used for financial reporting purposes under IFRS will differ substantially from the unit of property used for tax purposes. Tracking fixed asset additions and disposals, as well as analysing repairs to identify capital improvements based on different units of property is expected to be extremely complex and administratively burdensome. Overall, the impact will be highly individual, dependent on many factors, considerations will include taxpayer's overall tax situation, Fig. 4: Sample tax impact of selected differences between US GAAP and IFRS illustrates the possibilities.

Fig. 4: Sample tax impact of selected differences between US GAAP and IFRS

\begin{tabular}{|l|c|c|c|c|c|c|}
\hline $\begin{array}{l}\text { Current Year } \\
\text { Gain } \\
\text { (Deduction) }\end{array}$ & $\begin{array}{c}\text { US } \\
\text { GAAP }\end{array}$ & IFRS & $\begin{array}{c}\text { US Tax } \\
\text { Law }\end{array}$ & $\begin{array}{c}\text { Difference } \\
\text { between } \\
\text { US GAAP } \\
\text { and IFRS }\end{array}$ & $\begin{array}{c}\text { Difference } \\
\text { between } \\
\text { US GAAP } \\
\text { and US } \\
\text { Tax Law }\end{array}$ & $\begin{array}{c}\text { Difference } \\
\text { between } \\
\text { IFRS and } \\
\text { US Tax } \\
\text { Law }\end{array}$ \\
\hline LIFO & $(220)$ & $(150)$ & $(220)$ & $(70)$ & 0 & 70 \\
\hline Leasing & 0 & 800 & 800 & $(800)$ & $(800)$ & 0 \\
\hline $\begin{array}{l}\text { Component } \\
\text { Depreciation }\end{array}$ & $(150)$ & $(220)$ & $(220)$ & 70 & 70 & 0 \\
\hline Income (Loss) & $(370)$ & 430 & 360 & $(800)$ & $(730)$ & 70 \\
\hline
\end{tabular}

Source: Created by the author based on accounting and tax guidance.

Based on the current efforts by both IASB and FASB, most of the differences currently remaining between the two sets of accounting standards IFRS and US GAAP are going to be eliminated in foreseeable future.

\subsection{Tax accounting methods}

A "fresh start" conversion from US GAAP to IFRS allows companies a one-time opportunity to comprehensively reassess the accounting methods used for financial reporting purposes. Tax departments should assess the impact of possible changes in book methods by reviewing the US tax accounting methods of domestic entities with respect to the computation of taxable income and foreign entities with respect to the computation of earnings and profits. This comprehensive analysis of US tax accounting methods also provides tax departments a unique opportunity to identify optimal tax accounting methods that meet their tax planning objectives; for example, companies should consider whether to 
continue to follow the US GAAP method for tax if the present book accounting method is permissible for tax, to change to the new IFRS accounting method if that method is a permissible method for tax, or to change to some other acceptable tax accounting method that is preferable in light of their tax strategy. As a change in book and tax accounting methods resulting from an IFRS conversion could have a direct impact on a company's income tax reporting and cash taxes payable, careful consideration should be given to the implications of the company's accounting method choices on required method changes, cash taxes and tax compliance.

\section{State and local tax implications of transition to IFRS}

Not only federal authorities (IRS), but also state tax authorities and national companies prepare for IFRS adoption, since state and local tax calculations also heavily rely on accounting or federal tax results, both federal and state taxes will be affected by IFRS adoption. It is expected that a conversion to IFRS will impact a broad range of financial accounting methods (Deloitte, 2009); therefore, the financial accounting method changes in an IFRS conversion will require a thorough tax analysis to determine both the permissible and optimal tax accounting methods for both federal and state income tax purposes. To the extent federal taxable income changes in connection with an IFRS conversion, the corresponding change to state taxable income must also be considered, not only by taxpayers, but also by state taxing authorities.

Each state tax jurisdiction will have to decide whether or not their tax regime will follow the federal approach to IFRS. Taxpayers who operate in states that do not adopt changes to federal tax accounting methods may be required to maintain certain legacy accounting systems. These legacy systems will allow them access to information needed to continue filing tax returns in accordance with historical tax accounting methods. In addition to potential changes to state taxable income, companies may also see changes to their state apportionment percentages. State apportionment percentages are generally based on three factors: gross receipts, property, and payroll. These factors are weighted in accordance with each state's laws and regulations. Overall, IFRS adoption is predicted to impact not only state income taxes, but also franchise taxes, state net worth taxes and property taxes. The following is a discussion of some of the state and local tax impacts: 
- Changes to federal taxable income: To the extent book income changes as a result of the IFRS convergence, federal taxable income will change, unless the IRS takes action to provide some relief to taxpayers, and this will change also state taxable income for the states that use federal taxable income for their state tax base. Further complicating matters, there is no certainty that states will follow federal relief efforts, for example in the past, as a result of massive budget deficits, states have shown a propensity for decoupling from certain federal relief provisions, such as with IRC Section 199.

- Revaluation model: According to IFRS, IAS 16, Property, Plant, and Equipment, permits two accounting models: the cost model and the revaluation model, with the cost model currently used under US GAAP. The revaluation model requires that assets be carried at fair market value less any subsequent accumulated depreciation and impairment, with revaluations carried out regularly to ensure the carrying amount of an asset is not materially different than its fair market value. For companies, that would use the revaluation model under IFRS, the net worth or capital tax, ordinarily computed using historical book numbers, could exponentially increase, since generally speaking, to the extent a revaluation results in an increase in value, the increase should be credited directly to equity as revaluation surplus which accumulates in equity, and therefore should have an adverse impact on a taxpayer's net worth or capital-based tax liabilities.

- Uncertain tax positions: Divergence in US GAAP and IFRS guidance with respect to accounting for uncertainties related to income taxes may cause another issue for both federal and state tax considerations, because IAS 12, Income Taxes, does not address the treatment of uncertain tax positions and instead looks to IAS 37, Provisions, Contingent Liabilities and Contingent Assets, for guidance. This is contrasted with the ASC 740 two-step approach: (1) recognition: is the position more likely than not to be sustained based on its technical merits if all facts are known, and if so, (2) measurement: determine the amount of the potential benefit that can be recognized in the financial statements. IAS 37 employs a drastically different method by using the probability-weighted average of all possible outcomes to arrive at the expected 
outcome. Therefore, the potential of discovery and settlement can be considered when determining the potential financial statement benefit.

- Revenue recognition: IAS 18, Revenue Recognition, provides that revenue should be recognized when it is probable that any future economic benefit associated with the item of revenue will flow to the entity and the amount of revenue can be measured with reliability. While this treatment is not all that disparate from the revenue recognition rules under US GAAP, there may be some items that are either accelerated or deferred, whereby affecting a taxpayer's sales factor.

Other state issues, that will need to be considered include impact of changes to the treatment of stock-based compensation on the payroll factor; required move away from LIFO and the subsequent revaluation of inventories effect on the property factor; changes in the revenue recognition rules affect gross receipts taxes; revaluation model and property taxes.

\section{Non-technical tax issues related to IFRS adoption}

The area of other than technical impact of IFRS adoption on the administration of income taxes in USA has not been discussed as much as that of technical issues, as described in the previous sections. Some of the non-technical tax-related effects of IFRS adoption in USA include political lobbying, administrative burden, regulatory preparedness, professional education and academic impact (Hail, Leuz, \& Wysocki, 2009). The non-technical tax issues related to IFRS adoption either identified in academic research or by the profession can be summarized as follows, although the list is not exhaustive:

- Macroeconomic effects such as loss of tax revenue;

- Microeconomic effects such as increased compliance costs;

- Global tax structure of companies;

- Training of tax and accounting professionals and tax administrators;

- Academic research and educational opportunities;

- Political lobbying;

- Administrative burden; 
- Regulatory preparedness.

Apart from tax administration and regulation issues, the academic and professional community will also play an important role in the overall tax impact of the transition from US GAAP to IFRS and IFRS curricula are becoming more common on major business universities in USA (Jackling, Howieson \& Natoli, 2012). From the perspective of accounting professionals, the big four accounting firms and professional organizations have organized an education initiative to make sure that all tax professionals from not only the consulting sphere but also from the private sphere working as tax directors know what the change to IFRS means and how to prepare. Examples are PWC, who appointed a US IFRS tax leader and launched a IFRS tax considerations website, complete with advisory and compliance services; all other major accounting firms have similar initiatives and advisory services.

Only few researchers have addressed and attempted to quantify the issue of potential costs to various stakeholders with respect to tax impact of transition from US GAAP to IFRS, utilizing multiple approaches to estimating such costs. Smith (2009) utilized a survey of various academic, corporate and public accounting stakeholders, asking questions such as their estimated impact of the transition from US GAAP to IFRS, including the tax administration area related costs. Smith did not survey governmental stakeholders such as IRS or state regulators and no quantitative data was obtained in his survey, however, most stakeholders were unsure how tax regulations will change in response to the shift to IFRS, therefore could not estimate the impact on the associated tax costs, although most believed the compliance and tax-planning costs would increase.

Furthermore, Leuz et al. (2009) theorized that the main impact of the transition to IFRS would be concentrated with firms, who would have to respond to changes in both financial reporting rules and also tax regulations. Leuz also asserted that the preparedness of IRS to the switch to IFRS is presumed to be high; therefore the transition costs could be presumed minimal. To date, no quantitative research has been performed in this area, and would be much needed, however, the quantitative support is not readily available, as access to tax databases is restricted to private sources. Interesting research questions would include quantitative analysis of the impact of IFRS adoption on the quality of tax reporting in USA, including the impact of IFRS adoption on the gap between taxes that are due and the actual taxes reported. 


\section{Conclusion}

The transition from US GAAP to IFRS will not only impact the preparation of financial statements, it will have a noticeable effect on tax issues, due to the intertwined relationship of tax rules and regulations with US GAAP and the heavy reliance on financial reporting in tax compliance and regulation. The tax considerations discussed in this article are some of the implications that regulators, standard setters, profession, academics and companies may face when converting from US GAAP to IFRS. Regulators and standard setters are considering both tax and accounting rules and their interaction when creating new legislation. The profession is being proactive with continuing education and advisory services analysing industry impact in the tax reporting and planning area. When it comes to tax compliance, companies must reexamine their procedures for identifying and measuring book to tax differences.

Companies assessing the impact of IFRS on their organization need to keep the tax accounting method implications in mind and a similar analysis as in the US locations will be necessary for each jurisdiction in which a company operates, taking into consideration all of the country specific requirements for changes. Involving the tax profession in the assessment of accounting policy options is essential to gaining a complete picture of the potential benefits and drawbacks of the accounting changes that will result from conversion to IFRS because a complete analysis of a company's current tax accounting methods and consideration of the tax variables resulting from the IFRS conversion can help the company identify opportunities to mitigate potential tax accounting method issues and manage cash taxes. Deloitte writes that the possible impact is associated with product and financial supply chains, intangible transfers, shared service centres and entity rationalization (Deloitte, 2012).

The challenge for academics is to conduct quantitative research in this area, estimating the impact of the change from US GAAP to IFRS on both tax liabilities and administrative costs on both the tax authority and the taxpayer (macroeconomic and microeconomic impact.) Some commentators suggest that hundreds of book accounting method changes may result from a company's conversion to IFRS. Most of these book changes, however, are not expected to result in tax accounting method changes, instead, due to the many specific requirements in the tax law that must be followed in determining tax accounting methods, it is expected that changing book accounting methods from US GAAP to IFRS 
primarily will change the computation of, or possibly even eliminate, book and tax differences.

\section{References}

Blaylock, B. S. - Gaertner, F. B. - Shevlin, T. J. (2013): The Association between Book-Tax Conformity and Earnings Management (September 12, 2013). Review of Accounting Studies, Forthcoming.

Bothwell, J. L. (2009): Adopting international financial reporting standards for use in the United States: an economic and public policy perspective. FASB.

Chan, K. - K. Lin - P. Mo (2010): Will a departure from tax-based accounting encourage tax noncompliance? Archival evidence from a transition economy. Journal of Accounting and Economics vol. 50, no. 1, pp.58-73.

Deloitte (2009, January): IFRS Insights. Retrieved December 15, 2012, from Deloitte.com: www.deloitte.com

FASB (2013): Convergence with the International Accounting Standards Board (IASB). <http://www.fasb.org/intl/convergence_iasb.shtml>

Hail, L. - Leuz, C. - Wysocki, P. (2009): Global accounting convergence and the potential adoption of IFRS by the United states: an analysis of economic and policy factors. Independent research report to the FASB.

Hanlon, M. - E. Maydew - T. Shevlin (2008): An unintended consequence of book-taxconformity: A loss of earnings informativeness. Journal of Accounting and Economics, vol. 46, no. 2-3, pp.294-311.

IBISWorld (2014): Global Accounting Services Market Research, <www.ibisworld.com/industry/global/global-accounting-services.htm>

IRS (2010, September 10): Actions Are Being Taken to Address the Impact That International Financial Reporting Standards Will Have on Tax Administration. <http://www.treasury.gov/tigta/auditreports/ 2010reports/201030112fr.pdf>

IRS.gov (2011, November 5): Legal Advice 20114702F. 〈www.irs.gov> Jackling, B. - Howieson, B. - Natoli, R. (2012): Some implications of IFRS adoption for accounting education. Australian Accounting Review, vol. 22, no. 4, pp. 331-340.

Jaggi, B. - Low, P. (2000): Impact of culture, market forces, and legal system on financial disclosures. The International Journal of Accounting, vol. 35 , no. 4 , pp. 495-519. 
Roe, J.: Transition from US GAAP to IFRS: Analysis of Impact on Income Tax Administration in USA.

Leuz, C. - Pfaff, D. - Hopwood, A. (2010): The economics and politics of accounting: international perspectives on research trends, policy and practice. Oxford University Press.

Mulford, C. - Comiskey, E. (2008, December 14): The potential consequences of the elimination of LIFO as a part of IFRS convergence. Retreived October 10, 2014, <https://smartech.gatech.edu/handle/1853/ 26316>.

Mulyadi, M. - Soepriyanto, G. - Anwar, Y. (2012): IFRS adoption and taxation issues. International Journal of Arts and Commerce, vol. 1, no. 7, pp. 159-165.

Nobes, C. - Parker, R. (2012): Comparative International Accounting. Engelwood Cliffs, NJ: Prentice-Hall.

Nobes, C. - Schwencke, H. (2006): Tax and financial reporting links: a longitudinal examination over 30 years up to IFRS adoption, using Norway as a case study. European Accounting Review, vol. 15, no. 1, pp. 63-87.

PWC (2013, April): IFRS status by country. $<$ http://www.pwc.com/us/en/issues/ifrs-reporting/publications/ifrs-statuscountry.jhtml>

PWC (2014, February): IFRS in the US:The importance of being financially bilingual. <http://www.pwc.com/en_US/us/issues/ifrsreporting/publications/assets/pwc-ifrs-in-the-us-the-importance-of-beingfinancially-bilingual.pdf>

Ratcliffe, T. A. (2007): The Finer Points of Fair Value. Journal of Accountancy, vol. 103, no. 12, pp. 30-36.

SEC. (2014) www.sec.gov

Seidler, L. J. (1991): Technical issues in international accounting. Multinational Accounting: A Research Framework for the Eightees.

Smith, K., A (2009): Cost-Benefit Analysis of the Transition from GAAP to IFRS in the United States (2009). Honors Projects in Economics. Paper 9. http://digitalcommons.bryant.edu/honors_economics/9

Spalding, A. (2011): Mark-to-market and the widening gap between financial and tax accounting. Global journal of business research, vol. 5, no. 1, pp. 125-137. 


\title{
Transition from US GAAP to IFRS: Analysis of Impact on Income Tax Administration in USA
}

\begin{abstract}
When SEC and FASB started considering replacing US GAAP with IFRS, the impact of this change had to be considered by the various stakeholders in the financial reporting process in the U.S., including the various preparers and users of financial statements, including the Tax Administration, IRS. Since 2009, taxpayers in the U.S. are allowed to use IFRS as a starting point for reconciliation of book results to taxable income or loss, an option utilized by approximately 200 companies in that year. In 2010, TIGTA issued a report describing the state of preparedness for the potential transition from US GAAP to IFRS, outlining activities such as education of field agents, technical analysis of the potential impact of changes to financial reporting standards, consultation of current issues related to IFRS with taxpayers and preparers. Specific technical tax issues related to transition from US GAAP to IFRS include LIFO, leasing, component depreciation, and uncertain tax positions; non-technical tax issues related to IFRS adoption include taxpayer and agent education, regulatory adjustments, developing new audit strategies. In addition to federal tax considerations, state tax authorities and taxpayers are preparing for the impact of IFRS adoption on state and local tax administration, impacting issues such as sales, property, and payroll apportionment and equity-based taxes. The main research questions relate to empirical research related to the micro and macro economic impact of the transition from US GAAP to IFRS.
\end{abstract}

Key words: Tax administration; IFRS; US GAAP; IRS; TIGTA; LIFO; Financial reporting standards.

JEL classification: M41, H25 